\title{
The Saudi Little Leaders: The Current Status of Child's Participation Through Class and School Councils “Alshura Council” in Saudi Arabia
}

\author{
Bulquees Ismail Abdul Majid Daghistani \\ Professor of Educational Policies and Kindergarten Education \\ College of Education, King Saud University, Saudi Arabia
}

doi: 10.19044/ejes.v4no2a4 URL:http://dx.doi.org/10.19044/ejes.v4no2a4

\begin{abstract}
The objective of this study is to describe The current status of the Saudi Childs' participation through Class and School Councils "AlShura Council" as a way of increasing child rights in participation at a school level and democracy at a national level. The central two questions that guide this research are: How are the class and School Councils "AlShura Council" organized and operated at Saudi schools in relation to student participation? and, what are the experiences of student participation through Class and School Councils "AlShura Council" from the perspective of students? As the study design was a qualitative one-case study-, qualitative analysis is used to analyze the results. The results show that the establishment of Class and School Councils "AlShura Council” involves students in real decisionmaking processes. The students' voices are taken into consideration and that they are a part of decision-making processes at the school. Overall, the results seemed to suggest that by giving the children a chance of participation will benefit the students themselves, the school as a whole as well as the country in the work towards fulfilling the goal of increased democracy. Based on the results of this study, it is recommended that the prospects of initiating Class and School Councils "AlShura Council” at other schools in Saudi Arabia, as a way of increasing student participation, are both possible and achievable.
\end{abstract}

Keywords: Student, Participation, Class, School, Councils, Saudi Arabia, Child Rights, AlShura Council.

\section{Introduction and Background}

Increasing participation is about extending the goal of democracy to ensure that all citizens are prepared and able to contribute to shaping their own lives and their community. The culture of democracy implies that 
people learn to argue for their opinions and listen to the arguments of others, that they are prepared to change their views or to accept defeat in a vote. The earlier this is practiced and learnt, the better a democratic culture is established (Rubenson,1999). The United Nations Convention on the Rights of the Child (CRC), established in 1989, is usually described as a moral action plan where school is an arena for implementing children's rights and improving children's everyday life in school (Thelander,2009). A common abbreviation on the CRC is the child's right to provision, protection and participation, usually referred to as "the three pillars" can be seen as a starting point for working on the meaning and content of CRC (Bequele 2010; Wickenberg, 2009; Habashi , 2010). The right to participation, as defined in article 12, is one of the core principles of the CRC and is referred to as the "democracy article".

Childs' participation is beneficial both for children in their process towards becoming responsible and autonomous adults, as well as for the society as a whole (Corsaro, 2005). In this sentence, school as an institution plays a fundamental role in children's development and their incorporation of values and norms, as well as in promoting children's rights to participate in decision-making (Ehlers \& Frank, 2008; Thelander, 2009).

According to the CRC, article 12, child participation is defined as the right to take part in decision-making processes affecting one's life and the life of community in which one live capture the interactive and democratic aspects regarding participation. A democratic responsibility is reached only through practice and involvement and does not suddenly arise without involving children from the beginning to become competent and participating citizens (Matthews\&Limb, 1999).

Education plays a fundamental role in the overall development of a nation. Student consultation and participation is a way of improving the overall physical environment in schools. Particularly, in young democracies with young populations, schools are an important arena in the development of democratic values (Rasmusson,2011). Through active participation in schools, students can develop a feeling of being important, feeling welcomed and appreciated (de Winter, 1999).

Class and School Councils are a way of giving students an opportunity to participate in decision-making and to develop creative life skills, such as team-working, problem-solving, communication, negotiation and citizenship, which alter in good confidence and self-belief (Flutter, 2006). Students who are reporting that their school have effective Class and School Councils generally have a very positive attitude towards the overall social and academic aspects of school life, (Kirby\&Woodhead, 2003). 


\subsection{What is the School Council ?}

Flutter (2006) defined the School Council as a representative group of students who have been proposed and elected by their peers to represent their views and raise issues with the Senior Managers and Governors of their school. The School Council can also propose and take forward initiatives and projects on behalf of their peers, and be involved in strategic planning and processes such as the School Development plan, governing body meetings and staff appointments.

Kirby\&Woodhead (2003) stated that the object of an effective School Council is to help children and young people to:

- Enjoy and feel empowered by their education

- Feel that their school responds to their needs and views

- Have the opportunity to let adults know their feelings and opinions about things that affect them

- Have a say about decisions, and to play an active role in making their school a better place

- Develop life skills through participation.

\subsection{What are the duties of the Students Council?}

The duties of the Students Council include organizing events, programs and projects, encouraging democratic participation and striving to promote good citizenship by example. While Students Councils are generally given some autonomy in these duties, the school faculty will reserve the right to veto decisions or activities that run counter to the interests or policies of the school. (Rasmusson,2011).

The events, programs and projects arranged by Students Council's bodies might include any of the following:

- Food or clothing banks in the community

- Adopt-a-grandparent schemes

- Projects to improve the appearance of the school or grounds

- Tutoring programs

- Letter-writing campaigns (for example, to soldiers on Saudi borders)

- Events to raise funds and aid for disaster victims

Besides setting a good example for their peers, the other duties of Students Councils members depend on their specific title. The general members, or representatives, often simply have the responsibility of reporting back to the council from their homeroom. The Treasurer has the duty of maintaining financial records, and will work closely with the Secretary and an advisory member of the school faculty. The Secretary is responsible for official correspondence and taking notes during council meetings to keep a record of what has been said. The President, meanwhile, 
conducts the meetings with the assistance of their Vice President, who also assumes the President's role in case of absence.

The Saudi children are not away from these councils. They have AlShura Council, which has its own regulations. Most of the Saudi schools have AlShura council which is elected school students. The Council consists of a president, vice-president and secretary-general, and assistant secretarygeneral, and members (representatives) of the council. The Council hold its regular bi-weekly in the break, at the headquarters of the Council. The Council holds in some cases an emergency special session if the presence of two-thirds of its members is available. The Council relies on voting in taking its decisions, so that secret vote supporters of the resolution of the votes of the opposition, and in the event of a tie cuff is likely the voice of President of the Council, where the resolution shall be considered once the vote thereon. President of the Council put to a vote, does not participate in the voting, except when an equality of votes, then separates the two teams.

All topics for discussion in the Council should not exceed the affairs of the school, and it is obligatory to prevail over the official stamp of the Council meetings, and a commitment to the zenith, and idealism in the debate among members. The Council has the right to question the school board members, and faculty members, after a request from the President of the Council through the Secretary-General or his assistant of the President of the Advisory Council (educational leader for primary section) or the Secretary General of the Advisory Council and General Supervisor of Students Councils Affairs, before three days of holding Council meeting. Discussions are in the Council with faculty or staff members Board of Directors, in accordance with laws and regulations, so that members adhere to politely dialogue with respondents.The functions of the Secretary-General is to raise the initial reports for each meeting of the AlShura Council, to be evaluated before implementation,( Mohammad,2015).

Members of AlShura Council preside the following specialized committees:

1- Committee of Courses and Educational Attainment Affairs.

2- Committee of School Activity Affairs.

3- Committee of School Cafeteria Affairs.

4- Committee of Learning Environment Affairs.

5- Committee of Student Counseling Affairs.

6- Committee of Culture Affairs .

7- Committee of Student Affairs.

8- Public Relations Committee.

These committes have different functions and responsbilities to succeed the efforts of the school;for example: 


\section{1- Committee of Courses and Educational Attainment Affairs is} responsible about:

a- discussing all matters relating to the decision of the school curriculum in all subjects.

b- claiming the application of innovative ways to explain the lessons of some subjects.

c- activating the role of the teacher in motivating students to some symbolic gifts, and the application of the principle of reward.

2- Committee of School Activity Affairs is responsible about:

a- discussing all matters relating to the school for extracurricular activity.

b- proposing a number of activities that suit the school environment.

3- Committee of School Cafeteria Affairs is responsible about:

a- discussing all matters relating to the school canteen of the pros and cons, and organize the ranks of a queue.

b- assessing the meals provided, and make suggestions about improving for the students' interest.

4- Committee of Learning Environment Affairs is responsible about:

a-discussing all the educational environment of the school campus and outdoor arenas and stadiums, courtyards and internal and external school.

b-submitting of proposals to protect and care for those facilities from tampering with, or neglected image that reflect the civilized face of the school compound, the education, and the appearance of students.

c-taking care of school garden,watering methods so as to maintain normal life.

d- putting the draft to educate school students need to take care of and attention to public utilities for the school.

5- Committee of Student Counseling Affairs is caring about:

a-discussing all topics related to student guidance counselor with the student in school.

b-following daily duties letters for students, and discussing the pros and cons, with the student advisor.

c-presenting proposal tables for final exams, and tests at the middle of the season.

6- Committee of Culture Affairs is responsible about:

a- discussing all topics relating to culture. 
b- discussing the status of wall newspapers in the courtyard of the school, and make appropriate proposals about it

c- expressing an opinion about the school library, and make proposals to improve their conditions.

d- discussing the conditions of the morning school broadcast.

7- Committee of Student Affairs is responsible about:

a- discussing all matters pertaining to the students in the school

b- providing students with appropriate assistance after coordination with official persons in school.

c- submitting proposals to activate the stimulus side of the teachers and administration, for outstanding students

d- submitting proposals to activate the stimulus side of teachers and administration, for outstanding students in the activity.

8-Public Relations Committee is responsible about:

a- discussing all matters relating to public relations, outside the school environment.

b- inviting parents to attend some sessions, and inform them about the role of the Council.

c- constructing with the family in the community to provide the good image of the school.

d- organizing the educational forums for the members of the Council out of the school.

To sum up, all of the previous committees are working together to maximize the students' participation at school.They help to raise children's awareness about different school issues which leads to increase the feeling of loyalty and responsibilty twards their school and their country.

\section{Method}

\subsection{Design}

The current study design is a case study as it offers a great opportunity of understanding a phenomenon and explaining why some results can occur, more than just find out what those results are (Denscombe, 2009). Al-Rae'd Schools in Riyadh is chosen as one of the Saudi schools that has Student and School Councils "AlShura Council" to be studied deeply to explain why some results are occurred. The school has been concerning Class and School Councils "AlShura Council", for five years. Al Raed School is populated with approximately 1200 Saudi and Arabic students, graded from $1^{\text {st }}-12^{\text {th }}$.

Observation is an important way of getting to know the school environment. Flutter (2006) states that it is important that the researcher tries 
to understand the subject's actions by putting oneself into the observed context. During a six-week period, the researcher attended the school approximately two to three times per week. Furthermore, she did more systematic observations. In addition, another major method of collecting data was through creating focus groups of students and conducting semistructured interviews with them. The two focus groups were; 1) Students who were representatives at the School Council "AlShura Council". 2) Students who were not representatives at the School Council "AlShura Council". Each focus group was combined of 5-8 students between the ages of 6 to 8 years old. The focus group interviews were to create open discussions by initiating each meeting with different themes, like School Council “AlShura Council”, and student participation.

\subsection{Questions of the Study}

1- How are the Class and School Councils “AlShura Council” organized and operated at Saudi schools in relation to student participation?

2- What are the experiences of student participation through Class and School Councils "AlShura Council" from the perspective of early elementary students (Grade 1to 3)?

\subsection{Purpose of the study}

The purpose of the current study is to describe the current status of Class and School Councils "AlShura Council" at the Saudi schools. By describing and analyzing student participation, the researcher attempts to understand the meaning of participation and how the Class and School Councils "AlShura Council” are organized and operated in relation to the school activities regarding student participation in Saudi Arabia.

\subsection{Statement of the Problem and Significance of Study}

Saudi Arabia has been one of the participant countries, which has chosen to work towards increasing student participation in line with CRC article 12. Recently, Class and School Councils "AlShura Council" have been established in most schools of Saudi Arabia. But, the process of increasing democracy is not a straightforward process as it disrupts conventional expectations about power, authority and the role of children through nominating their members. With the lack of research on child participation within the field of education, the researcher tries to draw attention to the importance of student participation at schools as a way of increasing democracy in Saudi Arabia. 


\section{Results and Discussion}

The overall experiences presented by the participants were very positive and all participants indicated of a very positive change since the establishment of the Class and School Councils "AlShura Council”.

1- Question\#One: How are the Class and School Councils "AlShura Council" organized and operated at Saudi schools in relation to student participation?

At the target school, students organize the Class and School Councils "AlShura Council" in a way that every student is a part of it. The Class Council is described as a council, which is combined with students in a specific class. Every class forms its own Class Council with its own chairperson and secretary. Each and every student in democratic means, as they are called, elects these class representatives, in each class. In the election process, which is held once a year as new students are entering the school, every student writes down the name of the person they want to be their class representative. The winner becomes the chairperson and the one who gets the second most votes becomes the secretary. Further, the two class representatives from each class form the School Council "AlShura Council". This means that every class and grade from $1^{\text {st }}$ to $12^{\text {th }}$ is represented within the School Council "AlShura Council" through two representatives. In total, the School Council "AlShura Council" at the target school consists of 70 class representatives. The School Council "AlShura Council” has its own chairperson, vice chairperson, secretary, vice secretary and other executive members. As well as with the Class Council representatives, the executive members within the School Council "AlShura Council" are democratic and secretly elected by every student. The way it works is that the School Council "AlShura Council” representatives are running a one-day campaign each year where they present themselves in every class and the following day an election is held.

According to the order of the meetings of the School Council "AlShura Council" representatives, the School Council "AlShura Council" meetings are held three times per term. A typical Class Council meeting goes for approximately 45 minutes to one hour depending on the topics discussed. Normally, the meetings are held during school hours immediately after a break, usually on Wednesdays. The chairperson is in charge of the Class Council meeting; he or she is responsible to prepare, open and present the agenda of the day and taking down the notes.

After every Class Council meeting has been held, the 70 class representatives meet in the school hall as the School Council "AlShura Council" to speak on behalf of their classes, commonly on Sundays. The role of the School Council "AlShura Council" meetings is for the representatives to report what they have been discussing in their class. One by one, they 
represent the problems that their classes are facing and the achievements they want to be made. The duration of the School Council "AlShura Council" meetings is depending on the discussions held in the classes and the agenda of the day. The chairperson is responsible for holding and organizing the meeting. The secretary is responsible for publishing the discussions being held and the decisions that are made at all meetings. The School Council "AlShura Council" committee of executive members normally meet the following Monday after the School Council "AlShura Council” meeting. The committee is the one to meet the head of the school to report what have been discussed and the changes students want to be made. Further, the committee is responsible to bring up issues that the students are facing as they arouse in school. In collaboration with the head, they have to come up with a solution and decide, "How the school should be run".

Question \#2: What are the experiences of students' participation through Class and School Councils "AlShura Council” from the perspective of the students?

All participants expressed themselves in very positive terms to the concept of student participation and the establishment of class and School Councils "AlShura Council". They were happy to share the many positive changes that have been taken place. The Class and School Councils "AlShura Council" are given the students a platform to "air their views". This was expressed by the students, both in- and outside the School Council "AlShura Council". Through the Class and School Councils "AlShura Council" "everybody is free to express him/her self and it helps students to participate in important school matters" as expressed by the students.

The Class and School Councils "AlShura Council” enable students to make suggestions on how to develop the school to be a better school. This can be linked to Shier's (2001) opportunity stage of commitment, level two, where children are actually being supported in expressing their views. For the students outside the School Council "AlShura Council”, student participation means that all students are able to participate and being well aware of what the school is facing. It also means that students are able to share their opinions and problems with the School Council "AlShura Council”, to bring the issues to the head.

The Class and School Councils "AlShura Council" seem to give students the opportunity to be a part of different decision-making at school which moves student participation to the opportunity stage of commitment (Stern, 2006). The students expressed that they were involved in most decision-making at the school. This means that the students are becoming someone who can exercise influence and are in control of one's own situation. As students are becoming more involved, it changes the power structure at school from a top-down to a bottom-up perspective (Habashi, 
2010). The students themselves explained that they were a part of every decision-making concerning the school itself, except the things only considering teachers.

\section{Conclusion}

As a conclusion, it seems that student participation through Class and School Councils "AlShura Council" at the target school do not only contribute to increase democracy, but also enrich the students' current situation by seeing them as key-contributors in the improvements of the school. In addition, student participation is guided and encouraged in a number of activities at the school; at lessons, through debates, workshops and clubs.

\section{Recommendations}

Based on the results of this study, it is recommended that initiating Class and School Councils "AlShura Council" at other schools, as a way of increasing student participation, are both possible and achievable.

\section{Acknowledgment}

This is a research project that was supported by a grant from the Research Center for the Humanities, Deanship of Scientific Research at King Saud University 2016

\section{References:}

Bequele, A. (2010). Monitoring the commitment and child-friendliness of governments: A new approach . Child Abuse \& Neglect. Vol. 34 (1), pp 3444.

Corsaro, W. (2005). The sociology of childhood. (2nd Ed.) Thousand Oaks: Pine Forge Press.

De Winter, M. (1999). Enabling children: Participation as a new perspective on child - health promotion. Child: Care, Health and Development. Vol. 25 (1), pp 15-25.

Denscombe, M. (2009). Child's Participation through Class Council. Lund: Student literature Journal,Vol.20(1),pp27-35.

Ehlers, L. \& Frank, C. (2008). Child Participation . In Sloth-Nielsen, J. (Ed.), Children's rights, a legal perspective. Burlington, VT: Ashgate Pub. Company.

Flutter, J. (2006). This place could help you learn: student participation in increasing better school environments. In Education Review. Vol. 58 (2), pp 183-193. 
Habashi, J. (2010). Constitutional Analysis: A Proclamation of Children's Right to Protection, Provision and Participation. In International Journal on Children's Rights. Vol. 18 (2), pp 267-290.

Kirby, P.\&Woodhead, M. (2003). Children's participation in society. In Montgomery, H.; Burr, R.; Woodland, M (eds.) Changing childhoods: local and global. Haddington: Scotprint.

Matthews, M. \& Limb, M. (1999). Defining an agenda for the geography of children: review and prospect. In Progress in Human geography. Vol. 23 (1), pp. 61-90.

Mohammad,A.(2015).Regulations of the Consultative Council at Saudi Schools.EDUCATION Vol.38.(3),pp45-53.

Rasmusson, B. (2011). Mentor's report. In Advanced International Training on Child Rights, Classroom and School Management 2009-2010”. Lund University: Education/SIDA.

Rubenson, B.(1999). The rights of the child in Swedish Development Cooperation. Stockholm: Sida Press.

Shier, H.(2001). Pathways to Participation: Openings, Opportunities and Obligations in Children and Society. Vol. 15 (2), pp 107-117.

Stern, R. (2006). The Child's Right to Participation: Reality or Rhetoric? Uppsala: Uppsala University Press.

Thelander, N. (2009). We are all the same, but.. Swedish school children's views on children's rights. Karlstad: Karlstad University. 